\title{
THE CAUSES OF ADAPTATION DIFFICULTIES OF THE BEGINNING PUPILS
}

\author{
Radka Telekova
}

doi: 10.18355/PG.2020.9.2.4

\begin{abstract}
The nature of the pupil's adaptation at the beginning of school attendance is one of the important indicators of his development and a precondition for further school education. The beginning of school attendance includes especially pupil's everyday joy, achievement of better school results, building positive relationships in the new team. There is unsuccessful adaptation present in the pedagogical practice that is characterized by negative attitudes towards the school education and the appearance of the adaptation difficulties. In the presented theoretical analysis, we specify on adaptation difficulties with the emphasis on the causes of their existence in pupils at the beginning of the school attendance. The paper focuses on the selected areas which have the impact on the start of adaptation difficulties of beginning pupils. A broad-spectrum view of the occurrence of adaptation difficulties of beginning pupils allows the identification of their causes, the provision of adequate support and intervention to eliminate.
\end{abstract}

\section{Key words}

adaptation difficulties, adaptation, beginning of school attendance

\section{Introduction}

A beginning pupil is confronted with new conditions, formal activities, and responsibilities, the mastery of which requires an adequate level of skills and knowledge. If the resulting requirements of the school education are not at the level of the pupil's possibilities, then adaptation difficulties appear. The adaptation is necessary to be perceived as an interdisciplinary phenomenon and in pedagogical practise, it must be assessed within the individual components of the personality, the environment influencing its development. The level of the development in various areas and conditions in the given environments in which the child develops his/her own potential, can predict several causes of difficulties in the pupil's adaptation process at the beginning of schooling. The causes and manifestations of adaptation difficulties are different due to the individual peculiarities of the pupil within the physical, mental, and socio-emotional development (Boethel, M. 2004, Monkeviciene, O. a kol. 2006, Marturano, E.M. 2008). Reasons for adaptation difficulties are also found in the family, preschool and school environment, which also contribute to the success of the adaptation by their own degree of influence (Rimm-Kaufman, S., Pianta, C. R. 2000, Slezakova, T. 2012, Pratt, M. E. a kol. 2016). Existing research findings point to an increased occurance of pupil's adaptation difficulties at the beginning of schooling (Perry, B., Dockett, S. 2003; S. Burvyte, S. 2011; Kourkoutas, E. et al. 2011; Slezakova, T. 2012). Theoretical and practical knowledge of the 
adaptation process of each pupil requires recognition of its importance for further school education and personality development.

\section{Adaptation, adaptation difficulties of pupils at the beginning of school attendance}

The beginning of school attendance is a specific period in a child's life that brings many changes and requirements for the child, family, and school environment. The nature and length of adaptation is different among pupils since the individuals may react differently. School education brings a certain degree of yet unknown load towards to cognitive processes, socioemotional skills, physical preconditions. This is associated with difficulties in the period of adaptation, the causes of which exist in several areas affecting the development of the pupil.

In the professional literature, we find several definitions of the term "adaptation", the content of which is different with respect to the scientific field. A comprehensive view of adaptation is present in pedagogy, which in three aspects concretizes its multidisciplinary understanding. The general adaptation of an individual to society represents a socio-psychological aspect, which for pedagogical practice means the adaptation of the pupil to the requirements of the school in accordance with the acceptance of the socially obligatory role of the pupil. The beginning pupil acquires appropriate behaviour, establishes contacts with teachers and peers in the classroom, and forms teaching habits. Preventing and minimizing the presence of adverse effects is the starting point of the pedagogical aspect, which means adapting the school environment, respecting the individual peculiarities of the child. Adaptation in theory and practice includes the physiological aspect, i. e. knowledge of health status, possibilities of the organism and different levels of burden (Slezakova, T., Tirpakova, A. 2006). There are links between individual aspects, and so it is necessary to comprehensively respect them as a prevention of the emergence of the resulting threats.

Children perceive significant changes and the presence of differences associated with the beginning of schooling, which represents the entry into a relatively structured school life. Failure to correspond to the conditions of the educational process with the possibilities of children leads to the occurrence of adaptation difficulties. M. E. Marturano (2008) emphasizes the increased incidence of difficulties in the school environment during the transition from pre-school to primary education. A beginning pupil faces several tasks that result from his development, age and new stage. In school education he tries to succeed, in the class team he establishes friendly relations with peers, he acquires and respects the set norms.

In the professional literature, we find several definitions of the term adaptation difficulties. The terms maladaptation and maladjustation are used to denote them (Kopanyiova, A. 2009). Due to the defined meanings of the terms and content differences, we further prefer the terminological definition of adaptation difficulties as school maladaptation. (Marko, J. 1971, Praška, J. 2003, Slezakova, T. 2006, Prucha, E., Walterova, E., Mares, J. 2009) According to J. Marko (1971), it is a complete discrepancy or impaired harmony between school requirements and children's assumptions. O. Cacka 
(2009) approaches the concept of maladaptation in two levels - passive and active form. In the Pedagogical Dictionary (2009) maladaptation is characterized as bad, incomplete, and inadequate adaptation. The authors determine psychological, socio-cultural, economic deprivation as its causes. I.T. Babajevova (1990, In: Slezakova, T. 2006) names the difficulties arising in the period of adaptation with the term "adaptation disease", "school stress".

The given process, which is influenced by a number of factors, is therefore perceived as not corresponding to the conditions of the educational process with the possibilities and abilities of children. Although the beginning pupil tries to adapt successfully, this process is not successful. The result is a feeling of excessive and disproportionate burden, which has an impact on the emergence of adaptation difficulties associated with the feeling of failure, dissatisfaction, insecurity.

There are three levels or degrees of adaptation in the literature, which vary according to the time and quality of the related changes in the child's body. The first stage, referred to as easy and rapid adaptation, involves the disappearance of minor, diagnosed signs of difficulty within two months. The medium level of adaptation difficulties is limited to the duration of half a year. Its characteristics include the occurrence of inappropriate behaviour, playing during the lesson, non-response to the teacher's stimuli and there are emotional fluctuations associated with crying. The third, high degree of adaptation difficulties perceives their presence in the student for more than half a year. The problems relate to the rules of school life and the acquisition of the content of the curriculum, which reduces the school success and popularity of the student in the classroom. (Bezrukich, M. M., Jefimovova, S. P. 2000, Korotajeva, G. S. 2008, Slezakova, T., Tirpakova, A. 2006, In: Borbelyova, D. 2017)

\section{The causes of students' adaptation difficulties}

The emergence of adaptation difficulties is caused by a wide range of causes, which are different with respect to the individual peculiarities of the child. These are often unconscious phenomena and situations that become the cause of the difficulties present during the period of adaptation. Their content affects many areas of the child's life, whose personality is formed in the family, preschool and school environment. Existence in mutual interaction conditions several causes of future difficulties in the child's adaptation process at the beginning of schooling. We advise on the important tasks of the teacher to learn about the individual adaptation process of each student, to reveal related difficulties and their causes. Based on the successful identification of individual manifestations, the teacher can create conditions for their prevention, elimination, and provision of adequate intervention.

There are several examples of existing difficulties and identified causes in the literature. There is currently no revised structure of the causes and manifestations of adaptation difficulties. Their interpretation is different for the authors. We have identified common areas that have an impact on the incidence of adaptation difficulties of beginning pupils. (Vilcinskaja, B. J. 2000; Kovalevova, L.M, Tarasenko, NN 2001; Zvalova, M., Zvalo, P. 1999; 
Vagnerova, M. 1997; In: Slezakov;, T., Tirpakova, A. 2006, Homolova, T. 2015)

Picture 1: Areas affecting the emergence of adaptation difficulties.

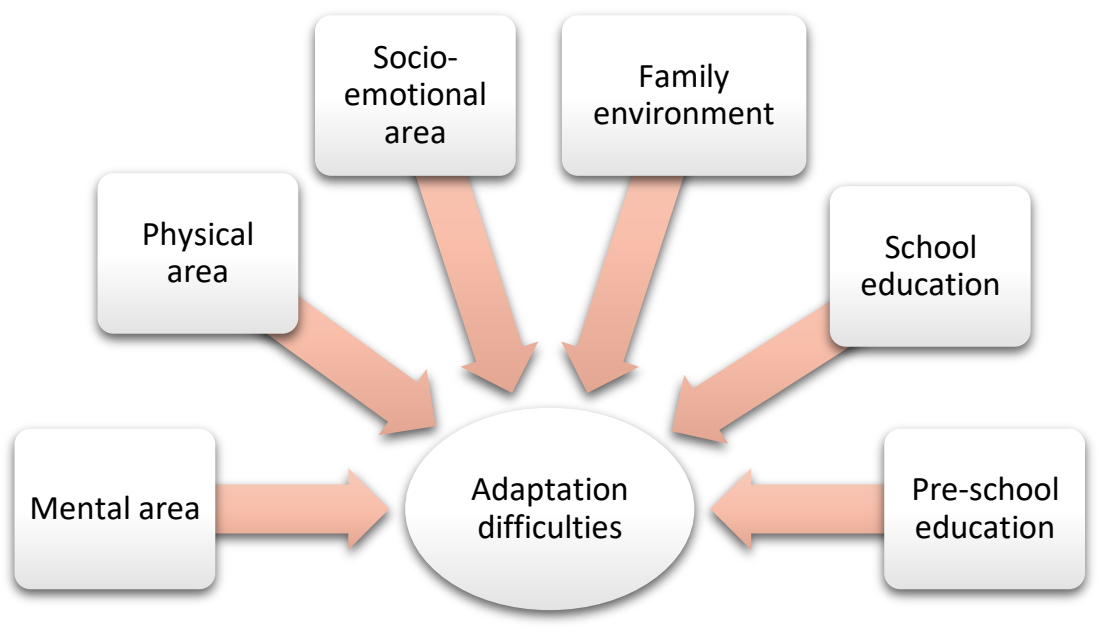

\section{Mental area}

The beginning of school attendance includes accelerated intellectual development, new ways of learning. School education presupposes a level of attention, concentration of the student and adequate performance. Demands for cognitive processes represent a burden on the mental area of the pupil's personality, in which adaptation difficulties may occur.

The child's intellectual level is identified during enrolment in primary school. On its background is the development of all cognitive and intellectual functions. As part of it, we also see gradually formed and improved metacognitive processes, which are stimulated in the child by the teacher, taking into account the existing knowledge structures and contexts (Duchovicova, J., Lazikova, A. 2008).

Before entering the first year of primary school, the attention of pre-school preparation and the family environment is focused on the increased cognitive level of the future pupil. In pedagogical practice, it becomes the most assessed area for managing the demands of primary education. During the period of adaptation, there are difficulties caused by cognitive impairments and mental deficiencies.

B. Perry and S. Dockett (2003) present research findings from interviews with parents, educators, and teachers. The content of the questions was oriented towards the beginning of school attendance and they compiled eight resulting categories from the answers. One of them was knowledge, facts and 
concepts needed to start primary education. Children talked about their importance more often than adults, expressing specific findings. Teachers mainly mentioned knowledge which is a part of diagnosing school readiness.

O. Monkeviciene et al. (2006) present the findings of selected authors (Belsky, MacKinnon, 1994; Entwistle, Alexander, 1998; Ladd, Price, 1987; Pianta, Kraft-Sayre, 1999), according to which the adaptation of pupils is conditioned by individual characteristics related to mental maturity, intelligence and competence of learning.

The future pupil is characterized by an increase in interest in typical school activities. Their implementation presupposes mastering the coherent components related to the child's personality, cooperation with the teacher and classmates, the nature of the activity. The child as an individual being, formed in a family and preschool environment, has different ideas and expectations regarding learning at school.

According to T. Slezakova (2012), the development of the child's mental functions is present through the active and initiative participation of the child in the role. Future schoolchildren carry out activities through which their cognitive interests, curiosity, and motivation to learn, to the school in general, are formed. The learning activity, which is the content of preprimary education, has specific characteristics in preschool age and acts in the sense of an education-cognitive task. An important prerequisite for increasing the success of initial teaching is the acquisition of the level of components of the class - cognitive task, which are to be developed throughout the pre-primary education.

Several authors (M.L. Kovalevova, N.N.Tarasenko, 2011; B.D.Elkonin 1988, In: Slezakova, T.2006) single out a disorder in intellectual activity, insufficient intentionality of mental functions, intellectual passivity as causes of difficulties at the beginning of school education.

\section{Physical area}

Before entering the 1st year of primary school, the dominant indicators of the physical development of the future pupil are also assessed. A sufficient level of gross and fine motor skills is a prerequisite for a successful beginning of school attendance. In the process of adaptation, motor-perceptual disorders are present, which become the causes of adaptation difficulties within the physical area of the beginning pupil.

T. Slezakova (2006) mentions the finding of J. Drobny (1965), according to which somatic factors belong to the causes of school burdens. In the set of assessed anthropometric indicators, students with adaptation difficulties had lower average values than other students. Existing differences were noted especially in girls. In this context, the cause of adaptation difficulties is the individual level of resistance of the organism to stress and the ability of the beginning pupil to manage the burden.

In their research, B. Perry and S. Dockett (2003) paid attention to parents' views on the physical attributes associated with starting school. Research findings show that parents see risks in adequate nutrition and rest of pupils. In the context of adaptation difficulties, it is possible to consider 
deficiencies in the given components as causes of difficulties that negatively affect the initial education of the pupil.

The physical development and health status of the child have an impact on the course of the pupil's adaptation. Before entering the 1st year, the physical maturity of the future pupil is assessed by a pediatrician, or another specialist. Weaknesses within the physical area cause easier fatigue, reduced resistance to stress, feelings of weakness, inferiority, or danger. J. Bednarova and V.Smardova (2012) draw attention to the risk of frequent illness at the beginning of school attendance. Absence from school for health reasons disrupts the smooth course of adaptation, complicates the building of relationships with classmates and teachers, increases the complexity of the content of the curriculum due to the lack of explanation by the teacher, conditions the feeling of fatigue and discomfort.

Pupils with different levels of physical development come to the first year. Individually, there are differences of varying magnitude, which are considered to be the causes of adaptation difficulties in the process of adaptation.

T. Slezakova (2012) presents problems with adaptation for students with disabilities, differences in the physical field. Appearance differences due to illness, different race, disability, impaired health, hyperactivity, slow psychomotor pace, or left-handedness. The mentioned causes complicate the course of adaptation, condition the occurrence of adaptation difficulties and the need for help for a specific pupil.

\section{Socio-emotional area}

Socio-emotional skills are important for existence in today's society. The teacher should know the appropriate options for strengthening these skills. The need for their development concerns all students, in the dominant attention are pupils with difficulties in adaptation or behaviour. In educational practice, it is a matter of combining knowledge with socialemotional skills, which represents an important basis for existence in school, in the family and in society.

The beginning of schooling also includes demands in the emotional and social area. Expectations towards a beginning pupil include emotional stability, emotion management, self-control, and a level of resilience. The existing differences between students represent a wide range of individual characteristics that are typical and unique for each of them. Emotional and social maturity, the level of social skills and adaptability have an impact on the existence of the pupil in the school and class team. In pedagogical practice, it is about joining a group of classmates, adequate communication, mastering and applying the rules of conduct, cooperation. The individual demands result from the role of a pupil, an important part of which is the role of a classmate. (Bednarová, J., Smardova, V. 2012)

At the beginning of schooling, pupils face difficulties in the socioemotional area. The presence of such problems prevents successful adaptation and social integration, which at the same time weakens the psychosocial development of the personality. 
According to B. Kasacova and M. Cabanova (2011), a beginning pupil should have motivational prerequisites, interest in learning, school activities. Socio-affective predispositions include experiencing joy and responsibility, building will qualities in order to achieve school success.

The concretization of the positive expectation of the school is the contrasting perception of the role of the pupil and the previous role of the kindergarten child. It is a well-perceived role through spontaneous and targeted confrontation with it, e.g. games in kindergarten. Ideas about the expected content and characteristics of the role of a pupil are expressed by children mainly through visible signs, while the school bag dominates in the statements as a differentiating element of a new elementary school student. Children associate their ideas with an increase in responsibility and independence, which copies the emphasis on reaching the age of six, considered a symptomatic expectation of cultural demands. (Pupala, B., Branicka, M. 2002)

At the end of pre-primary education or during the transition period, the child intuitively leaves the role of pre-schooler and gradually internalizes himself as a pupil. The child's entry into the first year of primary school relates to a new role of the pupil, which acceptance and mastery includes a set of requirements. T. Slezakova (2006) states that the unpreparedness and failure to cope with the new social role of the student is the cause of adaptation difficulties, learning difficulties and establishing contacts with the teacher or peers.

\section{Pre-school education}

Kindergarten has a specific position in preparing a child for entry into primary school. In addition to the framework requirements for formal education, it is important to consider the impact of the environment and the factors influencing the individual. Kindergarten training is characterized by a comprehensive approach and a universal impact of the educational environment on personality development. The conditions, resources and educational situations in pre-school education correspond to the peculiarities of pre-school children towards their purposeful improvement.

Z. Kollarikova and B. Pupala (2010) state that attention is paid especially in working with pre-schoolers, which also includes the assessment of school maturity and readiness. Preparation for school takes place by naturally developing the possibilities and abilities of children through play activities. At present, it is not only focused on increasing cognitive levels, but emphasizes children's confidence in their own strength, self-assurance, and optimal self-confidence.

Research findings point to differences between the school readiness of children with pre-primary education, which is at a higher level compared to peers without pre-school education. (Boethel, M. 2004) Kindergarten encourages the child's desire to become a pupil through artificial or spontaneous situations. B. Pupala and M. Branicka (2002) state that as an external differentiating feature, children communicate differences in the content of activities in primary school with a more intensive representation of learning and in kindergarten with game dominance. Children understand the 
need for gradual detachment from toys and play is characterized as a prerequisite for entering primary school, a suitable tool for "learning" in preprimary education. Pupils' expectations include serious learning responsibilities, institutional school learning activities, tasks and disciplines.

The course and duration of a pupil's adaptation at the beginning of school attendance is conditioned by the level of school readiness. Its acquisition, in accordance with the individual characteristics of the child, is the result of pre-school preparation in kindergarten. Based on research findings, T. Slezakova (2006) reports a longer duration of adaptation and the occurrence of adaptation difficulties for insufficiently prepared children.

In pre-primary education, it is important to emphasize the support of the child's inner strength, knowledge and adoption of strategies for orientation in various situations, overcoming obstacles and strengthening one's own will efforts. The current issues of positive psychology include increasing the student's psychological resilience, emphasizing the strengths of his personality and overall orientation to the student. In the context of the adaptation process, it is a matter of managing the resulting stressful situations by one's own efforts with the support of an adult (Fredrickson, L. B. 2001, Matthews, D. M. 2008).

Kindergarten has the opportunity to detect signals of adaptation difficulties through appropriate preventive activities. At present, they are given increased interest at the time of their occurrence, when they require the necessary solution. It is important to pay attention to the prevention of early manifestations of maladaptation of children entering the first year of primary school.

In the professional literature, the often-cited cause of adaptation difficulties is the non-completion of pre-primary education (Boethel, $\mathrm{M}$. 2004; Kovalevova, L.M., Tarasenko, N.N. 2001; Valentova, L. 2001; Vagnerova, M. 1997). Entering the first year brings unknown challenges and tasks typical of the period of adaptation. At the beginning of schooling, the pupil copes with the new environment, exists in interaction with unknown adults, creates a position in the class team and meets the requirements that have a formal character. Marturano, (2008) state that for a child without any previous education, are mentioned, similar task more difficult in comparison to children with a pre-school education.

Based on non-completion of pre-primary education, according to $\mathrm{T}$. Slezakova and D. Borbelyova (2017), beginning schoolchildren do not have acquired skills for working with classmates and teachers, making contacts in a group, respecting the rules of conduct and resolving conflicts. Their individually appropriate and potentially growing level is a prerequisite for a successful process of pupil's adaptation.

\section{Family environment}

Parents participate in the development of a pre-schooler in order to successfully enter the first year of primary school. The family environment is predominantly a source of support and assistance for a beginning pupil, but the causes of adaptation difficulties can be found in it as well. 
At the beginning of school attendance, each student is at an individual level of personality development, coming from unique conditions. The success of adaptation is influenced by different family conditions. J. Bednarova and V. Smardova (2012) mainly emphasize the level of support in the family environment, the quality of training in domestic conditions, the overall climate of the family. The demands of school education are more manageable for a mature child who is positively encouraged in the family.

The resulting changes not only concern the beginning pupil, but the necessary level of parental readiness is also expected for a child to enter school. The parents of a school-compulsory child change the usual ways and get acquainted with the related rights and obligations. T. Slezakova (2012) mentions the unpreparedness of parents who have insufficient ideas about the child's survival at the beginning of school attendance, the lack of information about the course of adaptation and ways of support, help in case of adaptation difficulties. Adequate cooperation with the teacher and the school environment is expected from the parents of the beginning schoolboy, which influences the success of the pupil's adaptation.

E. M. Pratt et al. (2016) addressed the factors that determine school readiness and the nature of adaptation, pointing to the risks in the family environment during the child's early childhood. Possible causes include insufficient cognitive stimulation by parents who do not carry out activities that encourage cognitive development with their children.

On the success of the adaptation or the occurrence of adaptation difficulties involves the family environment. Many of the pupil's adaptation difficulties at the beginning of schooling have their causes in the family. The family constructs the conditions for coping with the requirements of school education, the success of adaptation to the adequately known peculiarities of the beginning pupil.

The quality of the mutual relations between parents and children influences the pupil's school adaptation to which he transfers experiences from the family environment. Cognitive stimulation, a feeling of well-being, adequate reactions and expressions of interest in the child are prerequisites for the successful adaptation of a beginning pupil and his better results at school (Harvard Family Research Project, 2007).

\section{School environment}

From the point of view of a beginning pupil, the school environment has different characteristics than the previously known kindergarten environment. The beginning pupil finds himself in a new social environment of the classroom and peers, a school with its own regime and rules. Writing, reading and numeracy have a content-specific position in learning. For children, they are the educational tools necessary for existence in society.

In school education, an oversizing of the content of the curriculum appears, typical verbal methods and standard frontal work of students are applied. At the beginning of school attendance, the focus is on mastering trivia (reading, writing, counting) at a fast pace and with a focus on a set performance. The presence of the mentioned phenomena, the procedural side 
of the teaching process and the teacher's approach are the cause of pupils' adaptation difficulties (Slezakova, T. 2006).

The important person in a one's life is a teacher. The child is in daily contact with him on a different level compared to his parents. Primary school teachers attribute different characteristics to primary school teachers due to the different content of activities, the formality of the school environment, the level and form of contacts.

The relationship between the teacher and the beginning schoolchild influences the success of the pupil's adaptation. The nature of the interaction has an impact on the occurrence of adaptation difficulties. In pedagogical practice, it is considered to be the cause of weaker academic performance, negative attitudes towards school, a low level of involvement in school life and self-confidence. According to S. H. Birch and G. W. Ladd (1997), any disagreement, the conflict of the mentioned actors works as a cause of stress, burden and difficulties in the period of adaptation, but also later. The given character of the relationship limits its content, scope and quality.

In practice, anger, anxiety, loneliness, negative school attitudes, impaired academic performance and results are part of the mutual contact. Pupils who have a positive relationship with the teacher have adapted better to the school environment. Mutual relations were relatively close, nonconflicting, independent and had a direct impact on the success of adaptation, prevention of adaptation difficulties. Research findings suggest differences in the quality of relationships with teachers by gender of beginning schoolchildren. Teachers' statements suggest more conflicts and more negative relationships with boys. On the contrary, teachers have closer and more positive relationships with girls. Against the background of the above results, we see the influence of the teacher's gender and the overall, by research confirmed (Janosova, P. 2008) better adaptation of girls at the beginning of school attendance.

Entry into the first year of primary school determines the nature of the educational process, in which elements are present to ensure the successful adaptation of each student. Based on theoretical knowledge and practical experience, the teacher creates conditions leading to a smooth transition of students to primary school. In his work, he should consider the individual level of assumptions of the beginning schoolchild, which condition the individual attributes of the teaching process. According to T. Slezakova and D. Borbelyova (2017), it is expected that the starting point of teacher's work with beginning schoolchildren will be knowledge and experience regarding the main aspects of adaptation. In accordance with that, teacher should know the individual course of adaptation of each student, form the conditions and teaching in the classroom to prevent the emergence of adaptation difficulties.

The child's entry into the first year of primary school relates to the new role of the pupil, on the admission of which the kid is preparing at the end of pre-school education. In practice, it is an inevitable part of shaping the role of a pupil as well as the role of a classmate. The start of schooling also includes changes related to the creation and existence of the class collective. At the beginning of school attendance, it is necessary to pay attention to the 
formation of good relationships between classmates. The beginning pupil gets the opportunity to form an optimal position in the team of classmates independently, with the support of the teacher. Through everyday situations, he concretizes his interest in contact with classmates. A pupil who individually perceives an unsatisfactory position in the group is confronted with the occurrence of adaptation difficulties.

\section{Conclusion}

The successful course of adaptation of the pupil at the beginning of school attendance is conditioned by many factors that have an individual degree of influence on the personality of a freshman. The requirements of school education represent the claims to all components of the pupil's personality. In the interest of a smooth transition to primary school, adequate attention is expected to the pre-school, school, and family environment. In the process of adaptation, adaptation difficulties are individually present, the causes of which extend to several areas. Getting to know them includes many dimensions that encourage deeper theoretical and practical research. In the theoretical analysis, we drew attention to adaptation difficulties, their causes within the defined areas and environments shaping the personality of a beginning pupil. Sufficient attention is required to support the quality of adaptation to new school conditions, which will facilitate the transition to a relatively structured school life.

\section{Acknowledgements}

The paper was prepared with the support of a grant. Grant designation: V / 17/2020 (UGA UKF in Nitra) Title of the grant: Adaptation difficulties of pupils at the beginning of school attendance - their causes and manifestations.

\section{Bibliographic references}

BEDNAROVA, J. - SMARDOVA, V. 2012. Skolska zrelost. Co by malo dieta vediet pred vstupom do skoly. Brno: Edika. 99 p. ISBN 978-80-2660049-7.

BIRCH, H. S. - LADD, W. G. 1997. The Teacher-Child Relationship and Children's Early School Adjustment. In: Journal of School Psychology, vol. 35, n. 1, pp. 61-79.

BOETHEL, M. 2004. Readiness: School, Family and Community. Southwest Educational Development Laboratory.

BORBELYOVA, D. 2017. Adaptation to the School Enviroment in Early Elementary Education. In: Paidagogos. 2017, vol. 2016, n. 2, ISSN 12133809, pp. 206-228.

CACKA, O. 2009. Psychologie dusevniho vyvoje deti a dospivajicich s faktory optimalizace. Brno: Doplnek, 377 p. ISBN 80-7329-060-0

DUCHOVICOVA, J. - LAZIKOVA, A. 2008. Rozvoj osobnosti dietata a profesionalita ucitelky v materskej skole. Stimulacno - obohacujuci program KO-SE-TO pre materske skoly. Bratislava: IRIS, 249 p. ISBN 978-80-8925628-0 
FREDRICKSON, L. B. 2001.The role of positive emotions in positive psychology: The broaden and build theory of positive emotions. In: American Psychologist. 2001, Vol. 56, No 3, ISSN 0003-066X, pp. 218- 226. HARVARD FAMILY RESEARCH PROJECT, 2007. Family Involvement in Elementary school children's education. n. 2 in a series WINTER 2006/2007 HOMOLOVA, T. 2015. Adaptacia a adaptacne problemy ziakov v prvom rocniku primarneho vzdelavania. In: Psichologiceskij vademecum : psichologo-pedagogiceskoje soprovozdenie obrazovatelnogo processa $\mathrm{v}$ ucrezdenijach razlicnogo tipa. Vitebsk : VGU imeni P.M.Maserova, pp. 175182. ISBN 978-985-517-510-1,

JANOSOVA, P. 2008.Divci a chlapecka identita. Vyvoj a uskali. Praha: Grada Publishing. 288 p. ISBN 978-80-247-2284-9

KASACOVA, B. - CABANOVA, M. 2011, Pedagogicka diagnostika. Teoria a metody diagnostikovania v elementarnej edukacii. Banska Bystrica: PF, UMB. 136 p. ISBN 978-80-557-0328-2

KOLLARIKOVA, Z. - PUPALA, B. (eds.) 2010. Predskolni a primarni pedagogika. Predskolska a elementarna pedagogika. Praha: Portal. 455 p. ISBN 978-80-7367-828-9

KOPANYIOVA, A. 2009. Tercialna prevencia v skolstve. Bratislava: Vyskumny ustav detskej psychologie a patopsychologie, pp. 157-167, KOURKOUTAS, E. et al. 2011. Teachers' perceptions of pupils' social dysfunctions: A combined qualitative and quantitative approach In: Procedia Social and Behavioral Sciences 15 pp. 3870-3880

MARKO, J. 1971. Vpravovanie sa dietata do skolskeho prostredia. Bratislava: SPN

MARTURANO, E. M. 2008. Tensões cotidianas na transição da primeira serie: um enfoque de desenvolvimento. In: Psicologia em Estudo, Maringa, vol. 13 , n. 1 , pp. $79-87$

MATTHEWS, D. M. 2008. Positive psychology: Adaptation, Leadership and Performance in Exceptional Circumstantes. In: HANCOCK, A. P. SZALMA, L. J. (eds.) 2008. Performance Under Stress. England: Ashgate Publishing. 2008. ISBN 978-0-7546-7059-9, pp.163-180.

MONKEVICIENE, O. - MISHARA, L. B. - DUFOUR, S. 2006. Effects of the Zippy's Friends Programme on Children's Coping Abilities During the Transition from Kindergarten to Elementary School. In: Early Childhood Education Journal, vol. 34, n. 1,

PERRY, B. - DOCKETT, S. 2003. Starting school: perspectives of Australian children, parents and educators. Edinburg: The British Education Research Association Annual Conference.

PRATT, M. E. et al. 2016. Family risk profiles and school readiness: A person-centred approach. In: Early Childhood Research Quarterly, vol. 36, pp. $462-474$

PRUCHA, J. - WALTEROVA, E. - MARES, J. 2009. Pedagogicky slovnik. Praha: Portal, 395 p. ISBN 978-80-7367-647-6

PUPALA, B. - BRANICKA, M. 2002. Medzi materskou a zakladnou skolou: Co deti ocakavaju od skoly. In: Pedagogika, vol. 3. n. LII. pp. 337 - 345. ISSN 2336-2189, 
SLEZAKOVA, T. - BORBELYOVA, D. 2017. Several issues on school adaptation at primary level of education. In: Slavonic Pedagogical Studies Journal, vol. 6, n. 2, pp. 359-374, ISSN 1339-8660,

SLEZAKOVA, T. - TIRPAKOVA, A. 2006. Adaptacia dietata na skolu Sucasne pohlady na pedagogicku teoriu a prax. Nitra: PF UKF v Nitre. 191 p. ISBN 80-8050-968-9

SLEZAKOVA, T. 2012. Ucebno - poznavacia cinnost deti v najstarsej vekovej skupine materskej skoly ako dolezity predpoklad uspesneho zvladnutia roly skolaka. In: MINOVA, M. (ed.) 2012. Predprimarne vzdelavanie v sucasnosti. Zbornik z vedecko - odbornej konferencie. Presov: Pedagogicka fakulta Presovskej univerzity v Presove. pp. 123-131, ISBN 978-80-555-0703-3,

TELEGINA, N.V. - BELICHEVA, T.V. 2016. The criteria of adaptation of primary school pupils to the academic load of the increased intensity. In International Journal of Environmental and Science Education, vol. 11, n. 8, pp. 2059-2067.

YUKSEL, M. a kol. 2013. Analysing the school readiness of preschoolers from the aspect of the social skills when they start primary school. In: International Journal on New Trends in Education and Their Implications, vol. 4, pp. 98-112, ISSN 1309-6249

Mgr. Radka Teleková

Department of pedagogy

Faculty of education

Constantine the Philosopher University in Nitra

Dražovská cesta 4, Nitra

Slovak Republic

radka.telekova@ukf.sk 